\title{
Evaluation of Genetic Relationship of some Squirrelfishes through DNA Barcode
}

\author{
Lamiaa Elsayed Mokhtar Deef ${ }^{1 *}$ \\ https://orcid.org/0000-0002-4462-3432 \\ ${ }^{1}$ Damietta University, Faculty of Science, Department of Zoology, New Damietta, Damietta, Egypt. \\ Editor-in-Chief: Alexandre Rasi Aoki \\ Associate Editor: Marcelo Ricardo Vicari \\ Received: 2021.02.13; Accepted: 2021.04.25. \\ *Correspondence: lamiaadeef@du.edu.eg and lamiaadeef@yahoo.com; Tel.: +201006796514 (L.E.M.D.).
}

\section{HIGHLIGHTS}

- Confusion in the taxonomy of squirrelfishes was caused by the numerous nominal species.

- Our phylogeny provides a basis for evolutionary analyses of the Holocentridae.

- Silverspot squirrelfish was clustered as closest taxa to sabre squirrelfish.

\begin{abstract}
Species of the subfamily Holocentrinae, family Holocentidae, commonly called, squirrelfishes, are widely distributed from tropical to warm temperate waters. In Egypt, no data are available on genetic and evolutionary relationships of the family Holocentridae. Therefore, the study of the genetic relationship among Holocentrids species is crucial for proper management and convenient strategies. The purpose of this study was to evaluate the genetic relationship among eight species belonging to the family Holocentridae from the Mediterranean Sea and the Red Sea in Egypt using DNA barcoding. Based on this molecular marker, a phylogenetic tree was constructed for the studied Holocentrids species. 12S rRNA sequences discovered that Sargocentron caudimaculatum was clustered as closest taxa to Sargocentron spiniferum, being a sister group to each other. Also, Sargocentron punctatissimum and Sargocentron macrosquamis were more related to each other and formed a sister group. Moreover, this study discusses the building of genetic relationship among Sargocentron spinosissimum and Sargocentron macrosquamis for the first time to the other studied Sargocentrons. DNA barcoding using 12S rRNA gene provided efficient DNA barcodes for all of the studied species. The constructed phylogenetic tree based on the employed molecular marker provided the update for the barcoded Holocentridae species evolution.
\end{abstract}

Keywords: crowned; Holocentrinae; homocolour; nocturnal; Sargocentron

\section{INTRODUCTION}

The squirrelfishes (Holocentridae; Holocentrinae) are abundant members of tropical water assemblages [1], residing in caves and reef cracks during the day and foraging on the reef flat or in the water column at night [2, 3]). Genus Sargocentron has a great diversity among its species, which belongs to the Holocentridae family known as squirrelfish. Sargocentron is a pantropical genus includes 33 species [4], six species of Holocentrins are widespread in Egyptian cost [5]. Recently, Sargocentron spinosissimum and Sargocentron tiereoides are recorded for the first time in Egypt [6]. The novel findings of Sargocentron spinosissimum species that is distributed Northwest Pacific: southern Japan to Taiwan; also reported from Hawaii and 
Sargocentron tiereoides is distributed in Indo-Pacific regions and East Africa showed the success of the migration of these species to the Mediterranean water with a good adaptation to the new habitats [6].

Sargocentrons have compressed and elongated body with thin caudal peduncle; ridges and mucous channels dorsally on the head and have very large eyes. It has a single spine in pelvic fin with soft rays 5-8 (mode 7). Although dorsal fin long with 10-13 spines but, a notched soft-rayed part is found with 11-17 rays. Anal fin has four spines and 7-16 soft rays. Forked caudal fin has 18 or 19 rays. Scales are very rough ctenoid and large. Most Sargocentrons are brilliant reddish in color. Usually are nocturnal. Usually cryptic during the day in beneath ledges of reefs or crevices. Sargocentrons feed on worms and small fishes [7].

Due to features such as increased level of nucleotide sequence difference, rapid rate of evolution, compact genome and insufficiency of recombination, its maternal inheritance and higher mutation rates compared to those of nuclear genes, the mitochondrial DNA (mtDNA) has demonstrated to be valuable in molecular phylogenetic studies [8]. The mitochondrial 16S rRNA gene was used to explore the phylogenetic relationships of fishes at various taxonomic levels [9-11], mainly due to the fact that it is highly preserved and has a slow evolution [12]. Moreover, the 12S rRNA gene is considered a promising tool for tracing the history of more recent evolutionary events [13], and it has been widely used to study the phylogenetic relationships among different levels of taxa such as families [14-16], genera [17-20], and species [21, 22].

The confusion in the taxonomy of this subfamily has been caused by the numerous nominal species, their incomplete descriptions, loss of holotypes, and arbitrary synonymies [3]. The colour pattern and external morphology of Sargocentrons can be very similar among the different species, and this makes the recognition of members of this genus mostly difficult, there is a need to apply modern molecular techniques for more checking and confirmation in recognition and resolving the phylogenetic relationship among the studied squirrelfishes species.

\section{MATERIAL AND METHODS}

\section{Collection of Samples and laboratory procedures}

Thirty specimens of holocentrins were collected from different localities of the Egyptian coast. These specimens are: four samples from sabre squirrelfish (Sargocentron spiniferum), six specimens of the silverspot squirrelfish (Sargocentron caudimaculatum), two specimens of the Speckled squirrelfish (Sargocentron punctatissimum), two samples of the bigscale squirrelfish (Sargocentron macrosquamis) and three specimens of the crowned squirrelfish (Sargocentron diadema) were collected from Marsa Abu Dabab coast in the Red Sea. Six samples of the redcoat squirrelfish (Sargocentron rubrum) were captured from the Alexandria coasts. Additionally, four samples of the North Pacific squirrelfish (Sargocentron spinosissimum) and three samples of the pink squirrelfish (Sargocentron tiereoides) were collected from the Damietta coast of the north of Egypt, in the south-eastern part of the Mediterranean Sea. All locations of the study area (Figure 1) were visited throughout three years from October 2016 to September 2019.

The first member of the studied Holocentrins, sabre squirrelfish S. spiniferum (Forsskål, 1775), is widely distributed in Indo-Pacific [23] where it lives in a variety of coral reefs to a depth of at least $122 \mathrm{~m}$ [24]. This nocturnal species is the largest squirrelfish which feeds on crabs, shrimps and small fishes [25]. The second one, S. caudimaculatum (Rüppell, 1838), the silverspot squirrelfish, is native to the Indian and Pacific Oceans from East Africa to Japan and northern Australia and as far east as the Marshall Islands. It habitats near reefs, but can also be found at depths between 2 and $40 \mathrm{~m}$ [24].

The redcoat squirrelfish, S. rubrum (Forsskal, 1775), the third species, is among members of the family; Holocentrinae, is the first migrant Holocentrid to the Mediterranean Sea via Suez Canal and became the common immigrant Sargocentron species. It is the wide distribution from the Red Sea to the Indo- Pacific waters, [26], while the fourth member, S. diadema (Lacepède, 1802), known commonly as the crowned squirrelfish, is found in or near cracks and caves of coral reefs from 3-77 m, often in lagoons or bays at $<20$ $\mathrm{m}$ [27]. It is the most common species of Sargocentron wherever it is found.

S. macrosquamis (Golani, 1984), bigscale squirrelfish, the fifth studied Holocentrid species, lives in the western Indian Ocean; the Red Sea to Mozambique [7]. Moreover, the sixth member, S. punctatissimum (Cuvier, 1829), known commonly as the Speckled squirrelfish, lives in the Indo-Pacific; the Red Sea and Algoa Bay, South Africa [7]. S. spinosissimum (Temminck and Schlegel, 1843), North Pacific squirrelfish is the seventh member of the studied species which lives in Northwest Pacific, southern Japan to Taiwan; also reported from Hawaii [7], but recently, finds in the Mediterranean Sea [6], and the last one, S. tiereoides (Bleeker, 1853), pink squirrelfish, is habitats in Indo-Pacific [7], and lives in the Mediterranean Sea [6]. 


\section{DNA extraction PCR amplification}

Liver tissue was obtained from each Sargocentron specimen, then preserved in 95\% alcohol and stored in deep freezer at $-4^{\circ} \mathrm{C}$, where the Sargocentron species' DNA was extracted using a GeneJET ${ }^{\mathrm{TM}}$ kit Genomic DNA Kit\#K0721 following manufacturer's protocol.

12S rRNA gene was amplified using primers L1091-5' AAA AAG CTT CAA ACT GGG ATT AGA TAC CCC ACT AT-3' and H1478-5' TGA CTG CAG AGG GTG ACG GGC GGT GTG T-3' [28]. The polymerase chain reactions (PCR) consisting of approximately $50 \mathrm{ng}$ of template DNA were carried out in volumes of 15 $\mu \mathrm{l}$ with $1 \times$ PCR Buffer, $2 \mathrm{mM} \mathrm{MgCl}, 0.5 \mu \mathrm{M}$ of each FF and FR, $0.2 \mathrm{mM}$ of dNTP, and $0.6 \mathrm{U}$ of Taq DNA Polymerase. The thermal cycler started with an initial denaturation at $94^{\circ} \mathrm{C}$ for $4 \mathrm{~min}, 53^{\circ} \mathrm{C}$ for $2 \mathrm{~min}$, and $72^{\circ} \mathrm{C}$ for $1 \mathrm{~min}$ (one cycle); $94^{\circ} \mathrm{C}$ for $1 \mathrm{~min}, 53^{\circ} \mathrm{C}$ for $2 \mathrm{~min}$, and $72^{\circ} \mathrm{C}$ for $1 \mathrm{~min}(30 \mathrm{cycles})$; and $94^{\circ} \mathrm{C}$ for $1 \mathrm{~min}, 53^{\circ} \mathrm{C}$ for $2 \mathrm{~min}$, and $72^{\circ} \mathrm{C}$ for 5 min (one cycle).

PCR products were checked by running in 1.5\% agarose gels and stained with ethidium bromide. Successful PCR bands were cut out and purified using the QIAquick PCR purification kit from Quiagen ${ }^{\circ}$. The clean PCR products were sequenced using an automated sequencer following the manufacturer's protocols.

\section{Alignment and sequence properties}

All rRNA gene nucleotide sequences were aligned by using the Clustal $W$ software and identical sequences were considered as the same haplotype. Using MEGA X software [29], Kimura 2-parameter distance matrix of all studied species was calculated to construct a Maximum Likelihood phylogenetic tree.

\section{Basic Local Alignment Search Tool (BLAST)}

To investigate and recognize created sequences, each was blast searched as a request through NCBI (National Center for Biotechnology Information) Blastn tool (www.ncbi.nlm.nih.gov/BLAST/). Sequences with better hits were recovered and used for further comparison to 12S rRNA gene sequences from the current study. On the other hand, there is a lack of sequences for $S$. tiereoides, $S$. spinosissimum and $S$. macrosquamis.

\section{RESULTS}

The resulted 12S rRNA gene sequences of Holocentrids were submitted to the GenBank (NCBI) and the accession numbers were represented in table 1. Eleven sequences collected from NCBI belonging to various studied taxa were used for constriction of phylogram and genetic distance detection.

The average nucleotide frequencies are $36.1 \%(\mathrm{~A}), \mathbf{1 8 . 8} \%(\mathrm{~T} / \mathrm{U}), 23.4 \%(\mathrm{C})$ and $21.7 \%(\mathrm{G})$. The percent composition of nucleotide varied from 34.7 to $37.2 \%(\mathrm{~A}), 17.4$ to $19.7 \%(\mathrm{~T}), 21.8$ to $24.3 \%$ (C), and 21.2 to $22.1 \%(G)$, which indicate that $12 \mathrm{~S}$ rRNA gene sequences of these species are A rich and poor in $\mathrm{T}, \mathrm{C}$ and $\mathrm{G}$ (Table 2).

The transition/transversion rate ratios are $\mathrm{k} 1=16.475$ (purines) and $\mathrm{k} 2=34.049$ (pyrimidines). The content of pyrimidine was higher than that of purine. These values showed a strong $A+T(54.8 \%)$ to $G+C$ $(45.1 \%)$ asymmetry in nucleotide composition. The maximum AT content was found in $S$. diadema (57.1\%) and the minimum in S. spiniferum and S. spinosissimum (54.0\%). The maximum and minimum GC contents were observed in S. spiniferum (46.0\%) and S. diadema (43.0\%) respectively (Table 2$)$.

The genetic distance was calculated between the species included in the same genus of Holocentride. Distances calculated between species pairs showed that the smallest differences $(0.220)$ existed between $S$. punctatissimum and $S$. macrosquamis whereas the highest genetic distance detected between $S$. caudimaculatum and S. punctatissimum amounted to 0.271 (Table 3).

The topological structures of the tree illustrated that there are two mainly separate genetic branches, one branch for S. spiniferum, S. caudimaculatum, S. rubrum, S. spinosissimum, S. diadema and S. tiereoides and the other branch for $S$. punctatissimum and $S$. macrosquamis. The first branch divided into two separated groups, S. spiniferum, S. caudimaculatum, S. spinosissimum and S. tiereoides were included in group one while group two contained $S$. rubrum. In addition, $S$. caudimaculatum was more related to $S$. spiniferum and formed a sister group. Instead, S. diadema was lying into a separate group. The second branch consists of S. punctatissimum and $S$. macrosquamis which were more related to each other and formed a sister group (Figure 2).

In case of the mitochondrial tree, a total of eleven unique haplotypes were identified in sequences from $12 S$ rRNA gene of thirty specimens of Holocentridae. All haplotypes of $S$. tiereoides formed the monophyletic 
cluster with the clade included $S$. caudimaculatum and S. spiniferum. Moreover, this tree was splitting into two main clades, in the first clade, $S$. caudimaculatum was clustered as closest taxa to $S$. spiniferum, being a sister group to each other. Also, S. spinosissimum and S. tiereoides were placed in two different branches. Moreover, S. diadema was monophyletic clustered to S. spinosissimum and S. rubrum in this mitochondrial tree. In the second clade, the haplotypes of $S$. punctatissimum and S. macrosquamis were deposited together in the phylogram and appeared as a sister group (Figure 3).

Table 1. List of studied Sargocentrons members sequenced at mitochondrial DNA loci (12S rRNA gene) with a lack of sequences for S. tiereoides, S. spinosissimum and S. macrosquamis.

\begin{tabular}{lcc}
\hline Species & No. sequences & Accession number \\
\hline Sargocentron caudimaculatum & 1 & LC021252 \\
\hline Sargocentron spiniferum & 1 & LC492341 \\
\hline Sargocentron tiereoides & 0 & - \\
\hline Sargocentron spinosissimum & 0 & AB974507, LC458088, LC474169, \\
\hline Sargocentron rubrum & 6 & LC474170, LC474171, LC578992 \\
& & LC021238 \\
\hline Sargocentron diadema & 1 & - \\
\hline Sargocentron macrosquamis & 0 & LC069511, LC492342 \\
\hline Sargocentron punctatissimum & 2 &
\end{tabular}

Table 2. Percentage composition of nucleotides A, T, G, C, AT and GC in studied Holocentinae species.

\begin{tabular}{lllllll}
\hline \multicolumn{1}{c}{ Species } & A\% & T\% & G\% & C\% & AT\% & CG\% \\
\hline S. caudimaculatum & 36.6 & 18.0 & 22.1 & 23.3 & 54.6 & 45.4 \\
S. spiniferum & 36.0 & 18.0 & 22.7 & 23.3 & 54.0 & 46.0 \\
S. tiereoides & 37.2 & 18.0 & 21.5 & 23.3 & 55.2 & 44.8 \\
S. spinosissimum & 36.6 & 17.4 & 22.1 & 23.8 & 54.0 & 45.9 \\
S. rubrum & 37.8 & 17.4 & 21.5 & 23.3 & 55.2 & 44.8 \\
S. diadema & 35.3 & 21.8 & 21.2 & 21.8 & 57.1 & 43.0 \\
S. macrosquamis & 34.7 & 19.7 & 21.4 & 24.3 & 54.4 & 45.7 \\
S. punctatissimum & 34.7 & 19.7 & 21.4 & 24.3 & 54.4 & 45.7 \\
Mean & 36.1 & 18.8 & 21.7 & 23.4 & 54.8 & 45.1 \\
\hline
\end{tabular}

Table 3. Total genetic distance between the studied species.

\begin{tabular}{|c|c|c|c|c|c|c|c|c|}
\hline $\mathrm{cal}$ & S. & $\begin{array}{c}\text { S. } \\
\text { spiniferum }\end{array}$ & $\begin{array}{c}S . \\
\text { tiereoides }\end{array}$ & $\begin{array}{c}\text { S. } \\
\text { spinosissimum }\end{array}$ & $\begin{array}{c}S . \\
\text { rubrum }\end{array}$ & $\begin{array}{c}S . \\
\text { diadema }\end{array}$ & $\begin{array}{c}S . \\
\text { macrosquamis }\end{array}$ & $\begin{array}{c}S . \\
\text { punctatissimum }\end{array}$ \\
\hline S. caudimaculatum & 0 & & & & & & & \\
\hline S. spiniferum & 0.222 & 0 & & & & & & \\
\hline S. tiereoides & 0.227 & 0.233 & 0 & & & & & \\
\hline S. spinosissimum & 0.235 & 0.235 & 0.233 & 0 & & & & \\
\hline S. rubrum & 0.247 & 0.242 & 0.238 & 0.236 & 0 & & & \\
\hline S. diadema & 0.259 & 0.255 & 0.251 & 0.250 & 0.250 & 0 & & \\
\hline S. macrosquamis & 0.265 & 0.261 & 0.257 & 0.255 & 0.253 & 0.230 & 0 & \\
\hline S. punctatissimum & 0.271 & 0.268 & 0.262 & 0.258 & 0.255 & 0.239 & 0.220 & 0 \\
\hline
\end{tabular}




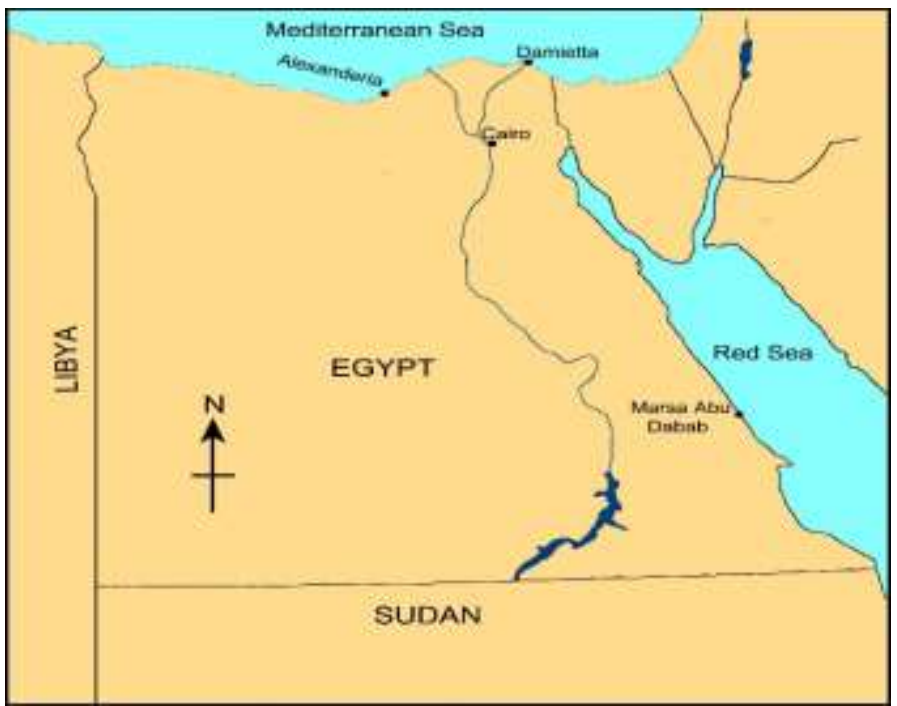

Figure 1. Map of Egypt showing localities of S. caudimaculatum, S. punctatissimum, S. macrosquamis and S. diadema were collected from Marsa Abu Dabab coast in the Red Sea. S. rubrum was captured from the Alexandria coasts. $S$. spinosissimum and S. tiereoides were collected from the Damietta coast in the Mediterranean Sea.

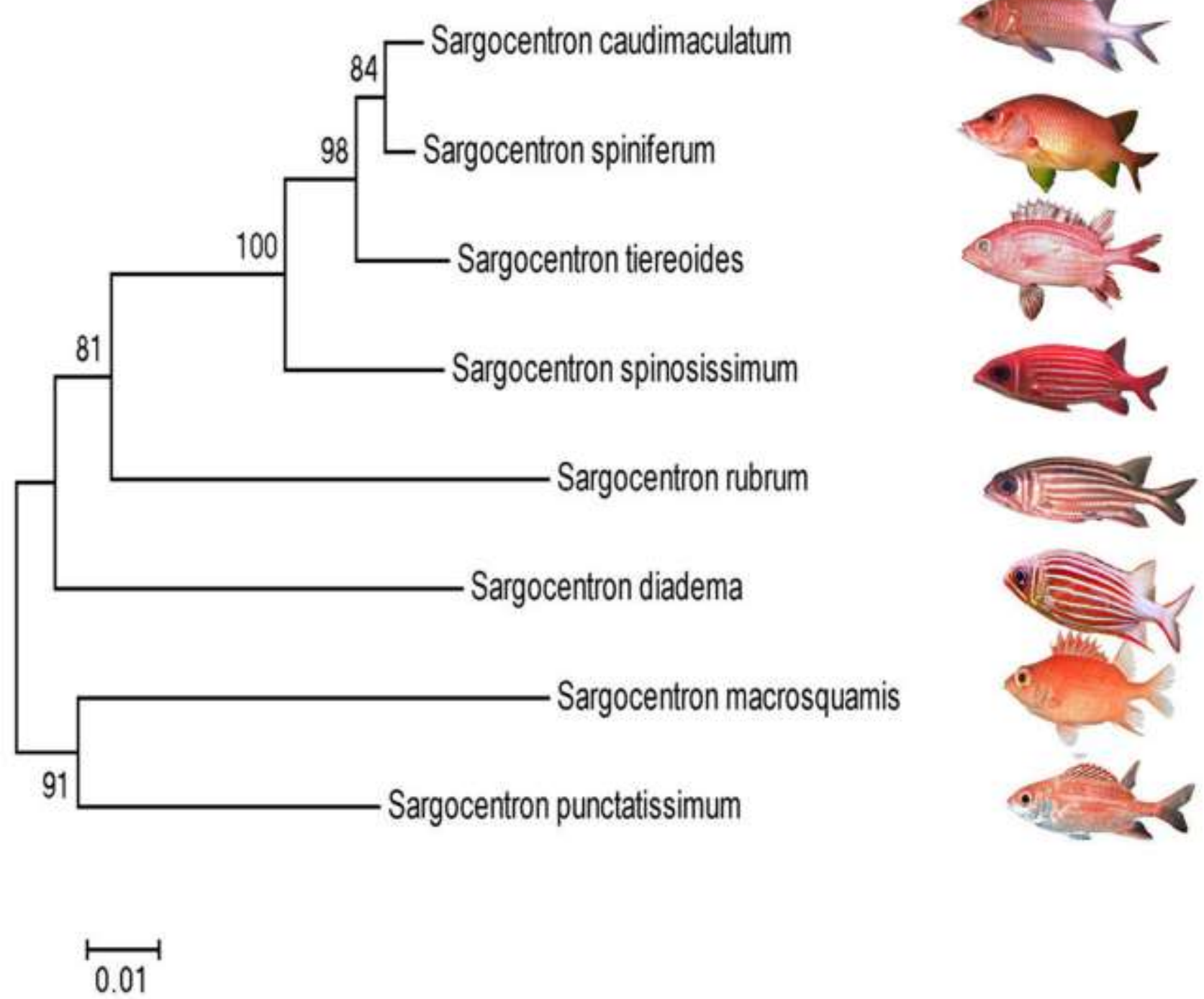

Figure 2. Maximum Likelihood phylogenetic tree based on 12S rRNA gene sequences of eight barcode sequences from the studied Sargocentron species, using Kimura 2-Parameter distances and values at nodes represent bootstrap confidence level (1000 replicates). 


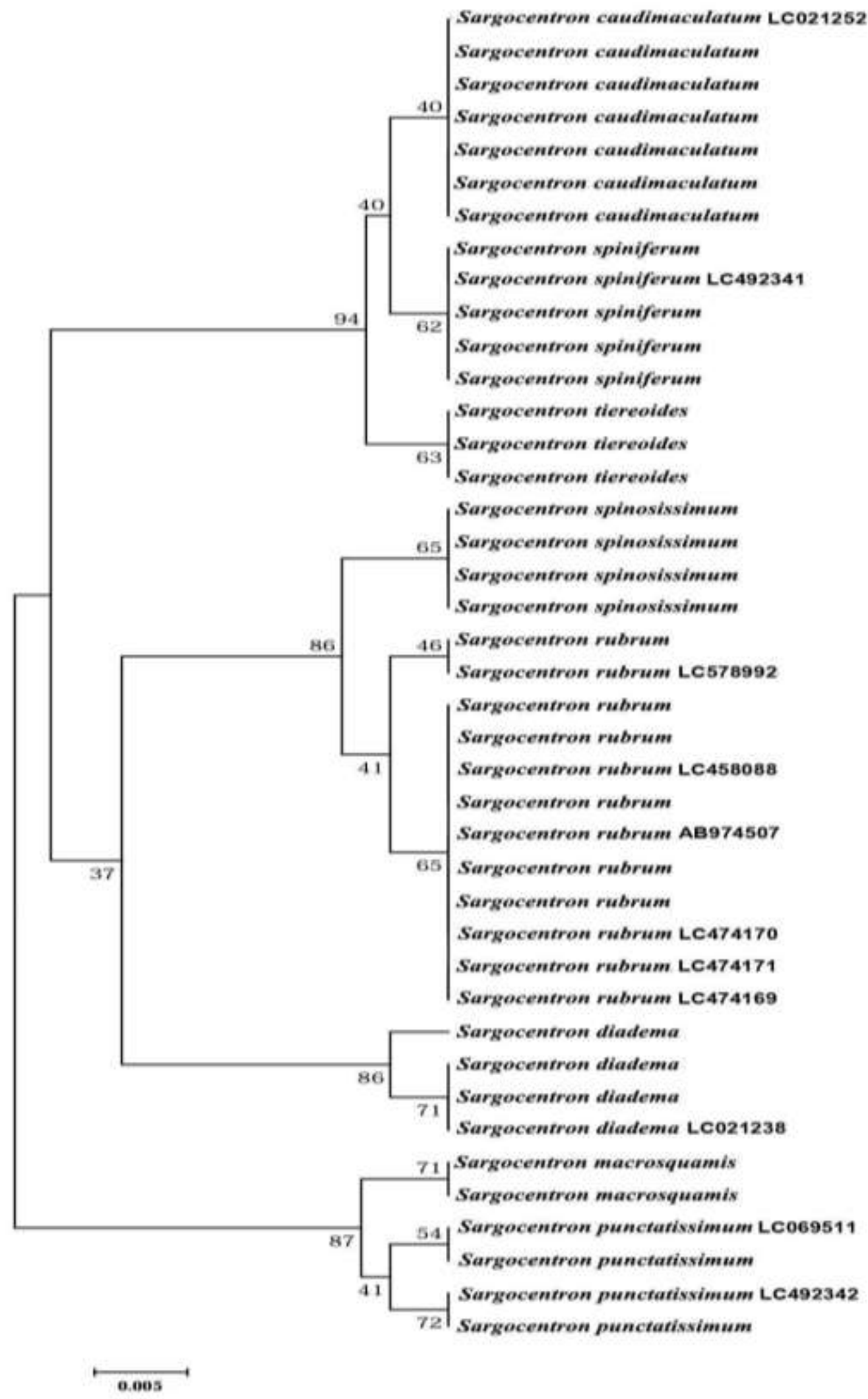

Figure 3. Kimura 2-parameter distance Maximum Likelihood tree analyses based on 12S rRNA gene from 41 barcode sequences from 8 species belonging to the family Holocentridae. The values at nodes represent bootstrap confidence level (1000 replicates). Specimen's number denotes the accession number of GenBank. 


\section{DISCUSSION}

Using DNA barcoding and molecular markers is nowadays essential since it represents a useful method for studying taxonomy and phylogenetic relationships among species. This technology has been taken as good tools for identifying species as well as in archaeological remains and museum samples because of the degradation nature and fragmentation of ancient DNA [30].

Previous studies were limited and insufficient to assess genetic relationships among Holocentridae species. Chen and coauthors [31] reported that $S$. spiniferumis sister to $S$. rubrum that belongs to the same genus. On the contrary, this study results that $S$. caudimaculatum was clustered as closest taxa to $S$. spiniferum in agreement with Dornburg and coauthors [32] and S. rubrum was laying into another clade.

The species of Sargocentron (S. spiniferum) is located within the first major clade of the Holocentrinae that includes several of the species identified by Woods [33] as the deep-bodied, more uniformly-colored, larger-sized species that he placed in Sargocentron (e.g., S. spiniferum, S. tieroides, and S. praslin).

The phylogenetic trees generated in this work, regardless of inference method, resolve the Holocentrinae into two main clades that are $S$. spiniferum, $S$. caudimaculatum, $S$. rubrum, $S$. spinosissimum and $S$. tiereoides which forms the first clade and the second clade for $S$. punctatissimum, S. macrosquamis and $S$. diadema. This genetic divergence may be related to spatial and temporal variations in recruitment [34], habitat effects [35] and other factors. Habitat availability [36] and habitat preferences [37, 38] also play a role.

The presence of $S$. spinosissimum and $S$. tiereoides in the Mediterranean Sea may be attributed to various studies that have to infer that physical variables, in particular substrate, depth, and currents, have a great influence on the distribution of fish and other aquatic organisms [39].

$12 S$ rRNA gene sequences discovered that $S$. caudimaculatum was clustered as closest taxa to $S$. spiniferum, being a sister group to each other. They are greatly look alike to each other and characterized by the absence of white stripes. Also, S. punctatissimum and S. macrosquamis which were more related to each other, formed a sister group, resemble each other and have homocolour without white stripes. Additionally, the study discusses the building of genetic relationships among $S$. spinosissimum and $S$. macrosquamis for the first time to the other studied Sargocentrons.

\section{CONCLUSION}

With the Holocentrids phylogenetic relationships resulted in this study, this aim to prompt a reexamination of genetic markers that have been used to diagnose and delimit taxonomic groups within the clade traditionally. This phylogeny provides a basis for subsequent comparative evolutionary analyses of the Holocentridae. The employed molecular marker in this study was efficient in species genetic diversification. $12 S$ rRNA was successfully utilized in species barcoding.

Funding: This research received no external funding.

Conflicts of Interest: The author declares no conflict of interest.

\section{REFERENCES}

1. Wyatt JR. The biology, ecology and bionomics of the squirrelfishes, Holocentridae. In: Munro JL (ed) Caribbean coral reef fishery resources. ICLARM Stud. Rev. 1983; 7. (Also appeared in Res. Rpt. Zool. Dept. Univ. West Indies (3):1-41, 1976).

2. Pankhurst $\mathrm{N}$. The relationship of ocular morphology to feeding modes and activity periods in shallow marine teleosts from New Zealand. Environ. Biol. Fishes 1989;26:201-11.

3. Schmitz L, Wainwright PC. Nocturnality constrains morphological and functional diversity in the eyes of reef fishes. BMC Evol. Biol. 2011;11:338.

4. Froese R, Pauly D. Fish Base. World Wide Web electronic publication. www.fishbase.org (1/2016).

5. Akel EH, Karachle PK. The Marine Ichthyofauna of Egypt. Egypt. J. Aquat. Biol. Fisher. 2017;21(3):81-116.

6. Deef LEM. First record of two Squirrelfishes, Sargocentron spinosissimum and Sargocentron tiereoides (Beryciformes: Holocentridae) from the Egyptian coast. Acta Ichthyol. Piscat. 2021;51(1):107-12.

7. Randall JE. Revision of the Indo-Pacific squirrelfishes (Beryciformes: Holocentridae: Holocentrinae) of the genus Sargocentron, with descriptions of four new species. Indo-Pacific Fishes 1998;27:1-105.

8. Avise JC. Molecular markers, natural history and evolution. 2nd ed. Chapman and Hall, London. 2004; $p 511$.

9. Orti G, Petry P, Porto JA, Jegu M, Meyer A. Patterns of nucleotide change in mitochondrial ribosomal RNA genes and the phylogeny of piranhas. J. Mol. Evol. 1996;42:169-82. 
10. Feng $Y$, Jing L, Peijun Z, Jianhai X. Preliminary study on mitochondrial $16 S$ rRNA gene sequences and phylogeny of flatfishes (Pleuronectiformes). Chin. J. of Oceanol. Limnol. 2005;23:335-9.

11. Li J, Wang X, Kong X, Zhao K, He S, Mayden RL. Variation patterns of the mitochondrial 16S rRNA gene with secondary structure constraints and their application to phylogeny of cyprinine fishes (Teleostei: Cypriniformes). Mol. Phylogenet. Evol. 2008;47:472-87.

12. Page RDM, Holmes EC. Molecular evolution: A phylogenetic approach. Blackwell Science, Oxford. 1998; p 172227.

13. Hillis DM, Dixon MT. Ribosomal DNA: molecular evolution and phylogenetic inference. Quart. Rev. Biol. 1991;66:411-53. doi: 10.1086/417338

14. Alves-Gomes JA, Ortí G, Haygood M, Heiligenberg W, Meyer A. Phylogenetic analysis of the South American electric fishes (order Gymnotiformes) and the evolution of their electrogenic system: a synthesis based on morphology, electrophysiology, and mitochondrial sequence data. Mol. Biol. Evol. 1995;12(2):298-318.

15. Douzery E, Catzeflis FM. Molecular evolution of the mitochondrial 12S rRNA in Ungulata (Mammalia). J. Mol. Evol. 1995;41:622-36.

16. Ledje $\mathrm{C}$, Arnason U. Phylogenetic relationships within caniform carnivores based on analyses of the mitochondrial 12S rRNA gene. J. Mol. Evol. 1996;43:641-9.

17. Gatesy J, Amato G, Vrba E, Schaller G, Salle RDe. A cladistic analysis of mitochondrial ribosomal DNA from the Bovidae. Mol. Phylogenet. Evol. 1997;7:303-19.

18. Murphy WJ, Collier GE. A molecular phylogeny for aplocheiloid fishes (Atherinomorpha, Cyprinodontiformes): the role of vicariance and the origins of annualism. Mol. Phylogenet. Evol. 1997;14:790-9.

19. Wang HY, Tsai MP, Dean J, Lee SC. Molecular phylogeny of gobioid fishes (Perciformes: Gobioidei) based on $12 S$ rRNA sequences. Mol. Phylogenet. Evol. 2001;20(3):390-408.

20. Wang $\mathrm{CH}$, Kuo $\mathrm{CH}$, Mok HK, Lee SC. Molecular phylogeny of elopomorphfishes inferred from mitochondrial $12 \mathrm{~S}$ ribosomal RNA sequences. Zool. Scripta 2003;32:231-41.

21. Murphy WJ, Collier GE. Phylogenetic relationships within the aplocheiloid fish genus Rivulus (Cyprinodontiformes, Rivulidae): implications for Caribbean and Central American biogeography. Mol. Biol. Evol. 1996;13:642-9.

22. Halanych KM, Robinson TJ. Phylogenetic relationships of cottontails (Sylvilagus, Lagomorpha): congruence of $12 \mathrm{~S}$ rDNA and cytogenetic data. Mol. Phylogenet. Evol. 1997;7:294-302.

23. Randall JE, Heemstra PC. Holocentridae. In: Smith MM, Heemstra PC, editors. Smiths' sea fishes. Berlin: SpringerVerlag. 1986; p 415-427.

24. Lieske E, Myers R. Collins pocket guide. Coral reef fishes. Indo-Pacific \& Caribbean including the Red Sea. Haper Collins Publishers. 1994.

25. Kuiter $\mathrm{RH}$, Tonozuka T. Pictorial guide to Indonesian reef fishes. Part 1. Eels - Snappers, Muraenidae - Lutjanidae. Australia: Zoonetics. 2001.

26. Allen GR, Erdmann MV. Reef fishes of the Bird's Head Peninsula, West Papua, Indonesia. Check List 2009;3:587628.

27. Mundy BC. Checklist of the fishes of the Hawaiian Archipelago. Bishop Mus. Bull. Zool. 2005;6:1-703.

28. Kocher TD, Thomas WK, Meyer A, Edwards SV, Pääbo S, Villablanca FX, Wilson AC. Dynamics of mitochondrial DNA evolution in animals: amplification and sequencing with conserved primers. Proc. Nat. Acad. Sci. USA. 1989;86(16):6196-200.

29. Kumar S, Stecher G, Li M, Knyaz C, Tamura K. MEGA X: Molecular Evolutionary Genetics Analysis across Computing Platforms. Mol. Biol. Evol. 2018;35(6):1547-9.

30. Pereira F, Carneiro J, Amorim A. Identification of species with DNA-based technology: current progress and challenges. Recent Pat. DNA Gene Seq. 2008;2(3):187-99.

31. Chen H, Zhou H, Wang X, Chen X. The phylogenomic position of the sabre squirrelfish Sargocentron spiniferum (beryciformes: holocentridae) inferred from the mitochondrial genome. Mitochond. DNA Part B: Resour. 2016;1(1):617-8.

32. Dornburg A, Moore JA, Webster R, Warren DL, Brandley MC, Iglesias TL, Wainwright PC, Near TJ. Molecular phylogenetics of squirrelfishes and soldierfishes (Teleostei: Beryciformes: Holocentridae): reconciling more than 100 years of taxonomic confusion. Mol. Phylogenet. Evol. 2012;65(2):727-38.

33. Woods LP. Western Atlantic species of the genus Holocentrus. Fieldiana Zool. 1955;37:91-119.

34. Doherty PJ. Spatial and temporal patterns in recruitment. In: Sale, P. F. (ed), The ecology of fishes on coral reefs. Academic Press, San Diego. 1991; p 261-293.

35. Williams DMcB. Patterns and processes in the distribution of coral reef fishes. In: Sale, P.F. (ed.), The ecology of fishes on coral reefs. Academic Press, San Diego. 1991; p 437-474. 
36. Caley MJ, Carr M, Hiscor HMA, Huges TP, Jones GP, Menge BA. Recruitment and the local dynamics of open marine populations. Ann. Rev. Ecol. Evol. Syst. 1996;27:477-500.

37. Caley MJ. Reef-fish community structure and dynamics: an interaction between local and larger scale? Mar. Ecol. Prog. Ser. 1995;129:19-29.

38. Tolimieri $\mathrm{N}$. The relationship among microhabitat characteristics, recruitment and adult abundance in the stoplight parrotfish, Sparisoma viridae, at three spatial scales. Bull. Mar. Sci. 1998;62:253-68.

39. Lasram F, Guilhaumon F, Albouy C, Somot S, Thuiller W, Mouillot D. The Mediterranean Sea as a 'cul-de-sac' for endemic fishes facing climate change. Glob. Change Biol. 2010;16:3233-45.

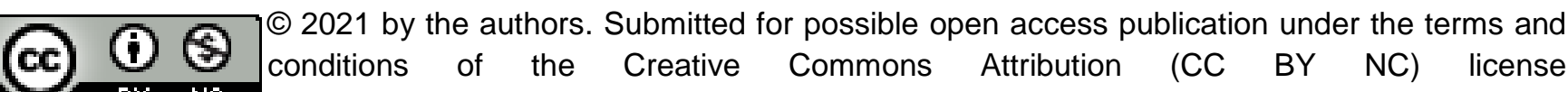
(https://creativecommons.org/licenses/by-nc/4.0/). 